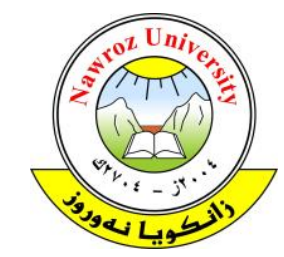

\title{
Effect of in-ovo injection of some natural oils on the hatchability and subsequent physiological responses of post hatch broilers
}

\author{
${ }^{1}$ Kurdman Sulaiman, ${ }^{2}$ Ihsan T. Tayeb \\ 1,2 College of Agricultural Engineering Science, University of Duhok, Kurdistan Region, Iraq
}

\begin{abstract}
This study was performed to determine the percentage of hatchability, post-hatch growth performance, and immune response of broiler subjected to in-ovo injection of some natural oils. A total of 360 eggs of ross broiler strain were obtained. Eggs were distributed into six groups: T1,Negative Control (No injection), T2, positive control (injected with $0.1 \mathrm{ml}$ distilled water; T3 injected with $0.1 \mathrm{ml}$ of rosemary oil ; T4, injected with $0.1 \mathrm{ml}$ of black seed oil; T5 injected with $0.1 \mathrm{ml}$ of olive oil, and T6, injected with $0.1 \mathrm{ml}$ of almond oil. The newly hatched chicks were distributed into 6 groups of 4 replicates of 10 chick. Higher hatchability percentage was found in rosemary oil, followed by almond oil and olive oil -injected eggs. The final weights of birds that were hatched from rosemary oil, and black seed oil -injected groups were significantly $(\mathrm{P}<0.05)$ higher than other experimental groups. Feed intake and feed conversion ratio were improved with in -ovo administration of rosemary oil and black seed oil. In addition, the level of blood cholesterol and blood glucose were decreased $(\mathrm{p}<0.05)$ in birds from all-natural oils-injected eggs. The level of IgM and IgG was significantly $(p<0.05)$ increased in the serum of birds that were hatched from natural oils injected eggs. It could be concluded that in-ove injection of natural oils used in this study was promising to increase the hatchability percentage and improve the subsequent growth and immune responses of post hatched birds.
\end{abstract}

Keywords: Hatchability; In-ovo Injection; Natural Oils; Broiler; Immunity.

\section{Introduction}

Poultry industry is continuously developing in many sectors including genetic, breeding and nutrition. Improvement in the performance and the production capacity was the reflex to this development, thus broilers are reaching to the marketing age and weight sooner each year. This fast growth and huge performance development was always faced many health problems which were controlled by using sub therapeutical doses of antibiotics ((Mahasin and Zahida, 2010).The use of antibiotics in both disease controlling and growth promoting aspects was positively effective.

Antibiotics assist controlling infections in gut mucosa, and reduce disease susceptibility, therefore they have been used as a principal growth promoting substances in poultry diets for many years (Al-Mufarrej, 2013) . However, in 1996, the use of antibiotics were prohibited by European Union ( Toghyani, et al, 2001) ). The main reason behind this trend is the risk of antibiotics crossresistance among pathogens and its residues remain in tissues which affects human health (Schwarz et al., 2001). Therefore, finding the natural compounds that have the potential to be possible alternatives to antibiotic growth promoters is becoming a must by specialists in poultry industry. Subsequently following the restriction of the use of antibiotics, plant origin feed additive particularly essential oils have gained the growing interests. 
Essential oils possess antimicrobial, antioxidant and digestive stimulant properties (Placha et al., 2010, Platel and Srinivasan, 2004) due to its content of biological active compounds.

The positive effects of dietary essential oil on feed conversion efficiency, egg production (Cubuk et al. ,2006) performance, immunity, eggshell quality and egg weight (Buolükbasi et al., 2008) in layer hens has been confirmed by previous studies.

However, researcher indicated that only about $20-30 \%$ of food additives in breeder feed transported to their eggs, while the other big part of those foods remains in bird's body (Abdul -Lateif and Abdulateef, 2012). Thus, direct insertion of these substance into the egg was used and the results were favorable ( Villaluenga et al., 2004; Maiorano et al., 2012)

The in -ovo injection of these oils might provide poultry companies with an alternative to antibiotics to increase the immunity and the weight of the newly-hatched chicks (Ohta et al., 2001).

This study aimed to investigate the effect of in-ovo injection of some natural oils (Almond oil, black seed oil, olive oil and rosemary oil) on hatchability percentage, chick quality, production performance, and the immunity of the newly hatched chicks

\section{MATERIALS AND METHODS}

\subsection{Experimental site}

The experiment was conducted at the poultry farm of Animal Production Department, College of Agricultural Engineering sciences, University of Duhok, Kurdistan Region, Iraq.

Experimental design, in-ovo injection and post hatch chick's husbandry

A total 360 eggs of Ross broiler strain were obtained. Eggs were stored in a cool-humid storage area with a temperature of $17^{\circ} \mathrm{C}$ and $75 \%$ relative humidity. On the 18th day of incubation eggs were injected with $0.1 \mathrm{ml}$ rosemary oil, black seeds oil, olive oil, and almond oil on the allantoic sac (Table 1).

The newly hatched chicks were distributed into 6 treatments of 4 replicates of 10 chicks per replicate, and reared in floor cages, wood shaving was used for bedding. Feeders and drinkers were provided under standard management conditions. Two feeding phases were provided: starter (1-21) and finisher (22-35). During the experiment feed and water were provided ad libitum.

All diets were prepared approximately one week before the beginning of the experiment and offered in its mash form throughout the experimental period. The composition of all diets is presented in Table (2) The dietary formulation was based on the recommendation of Ross 308 management handbook (2018).

\subsection{The Studied Traits}

\subsubsection{Hatchability percentage, and post hatch chicks} body weight.

i. Performance parameters:

Performance parameters include the body weight, feed conversion ratio (FCR), and feed intake. at days 7, 21 and 35 the birds feed leftover was weighed to calculate the average weight, feed intake and feed conversion ratio.

\section{ii. Mortality Rate:}

Mortality rate was calculated as the number of mortal birds from a total number of broilers during whole period of the experiment.

\section{iii. Blood samples collection:}

At day 35, blood samples $(4.0 \mathrm{ml})$ of 8 birds from each treatment were collected from the wing vein. Subsequently serum was harvested after centrifugation. Serum was analyzed for immunoglobulin (IgG,and IgM), T3, T4, total cholesterol, triglyceride content, total protein and glucose. Serum biochemical parameters were determined by colorimetric enzymatic methods following the procedures provided in the used 
corresponding commercial kits provided by (Randox laboratories limited, United Kingdom).

\subsection{Statistical Analysis}

For determining the significance of main effects, The statistical package, SAS (PROC GLM) was used (SAS, 2013). To indicate the differences between means of individual element, Duncan's multiple range tests was used. The chosen level of significance was $\mathrm{P} \leq 0.05$.

\section{RESULTS AND DISCUSSION}

\subsection{Hatchability \% and post hatched chicks body} weight

Impact of in-ovo injection of some natural oils on hatchability percentage and post hatch chicks' weight is shown in Table 3. The effect of in-ovo injection of some natural oils was not-significant on post hatched chicks body weight. While, the percentage of hatchability was highest $(p<0.05)$ in eggs injected with rosemary oil, followed by those injected with almond oil, and olive oil compared to positive control group. Eggs injected with black seed oil had no-significant effects on hatchability percentage compared to positive control. While, the hatchability percentage was decreased to $74 \%$ in eggs injected with the distilled water. These results are in line with Radwan et al. (2008) finding who concluded that hens receiving $1 \%$ thyme in their diet followed by $1.0 \%$ rosemary had the highest percentage of hatchability respectively. These results could bring to an end that rosemary, olive oil, and almond oil had a favorable effect on hatchability, and antioxidant activity might be the main reason behind this trend (Galobart et al., 1999; Ajuyah et al., 1993; Cherian et al., 1996 Farag et al., 1989; Deighton et al., 1993) . Carnosic acid, an antioxidant compounds present in these oils pass on to eggs and deposit into yolk which increase the mechanism of adaptation to treat the over production of free radicals; which consequently improve hatchability (Botsoglou et al., 1997; Krause and Ternes, 1999; Galobart et al., 2001a, Radwan et al, 2008).

\subsection{Growth Performance}

At day 7 and 21 of broiler age ,a significant $(p<0.05)$ difference has been detected among the experimental groups in regards to body weight indicating the highest body weight of bird subjected to in-ovo administration of rosemary oil and black seed oil compared to other treatments groups ( Table4). While, no significant difference was recorded between other treatment groups. At day $35 \mathrm{f}$ age the final body weight of birds from both rosemary oil and black seed oil injected eggs groups was improved compared to control group. While, birds from almond oil injected eggs group had the lower body weight compared to control group.

This could be attributed to the antimicrobial activity of the essential oils thereby improving the gut ecosystem and microbial community via decreasing the number of pathogenic microorganisms in the gastrointestinal tract of birds (Windisch et al., 2008; Castillo et al., 2006 ). Controlling the microbial activity may decrease the production of volatile fatty acids and stabilize the intestinal $\mathrm{pH}$ which may provide the ideal environment to the digestive enzymes to activate (Jamroz et al., 2003). This may in turn increase the availability and better utilization of nutrient especially protein thereby improving the digestibility and absorptive capacity of the digestive system

These results were in agreement with Ghazalah and Ali (21) finding who showed that broiler diet supplemented with rosemary leaves at a rate of $0.5 \%$ improved broiler performance, as well as the quality of meat was highly acceptable by consumer. Same results were recorded by Mathlouthi et al. (2015) when added rosemary essential oils to the diet which increased the mean body weight of 
broiler chicken. Al-Kassie et al. (2008) declared that supplementing of rosemary at levels 0.5 and $1.0 \%$ to the diet increased growth rate of broiler at age 42 days. On the other hand, Yildirim at al. (2018) concluded that diet supplemented with rosemary decrease the feed consumption and body weight in comparison to control group and it also does not have any influence on feed conversion rate.

Results of black seeds are in line with Guler et al., (2006) finding, who indicated that broiler performance and carcass yields of broilers were improved by dietary supplementation of black seed at the level of $1 \%$, and concluded that black seed could be used as a natural growth promoter in poultry diets. Suhail et al., (2012) indicated that broiler performance was improved by addition of black seeds to their diet suggesting these seeds to be a possible alternative to antibiotics.

Black seeds in the digestive system possesses antimicrobial effects against pathogenic bacteria, parasite and fungi existed in the digestive tract, which might be the main reason of the positive effect of black cumin seeds on broiler performance (Gilani et al., 2004). Controlling the gut micro flora have a positive impact on broiler performance (Guler et al.,2006). Frthermore, traditionally for the treatment of gastrointestinal disorders, black seeds have been used (El-Abhar et al., 2003). The biological functions of black seed not only serve as antioxidant, antifungal, and antibacterial, but it also helps the stimulation of digestive enzymes in the pancreas and mucosa (Guler et al., 2007; AbuDarwish,,Abu-Dieyeh ,2008). Combination of all the active ingredients in the black seeds might have a positive impact in improving broiler performance.

\subsection{Feed intake, feed conversion ratio and Mortality}

The data in table (4) indicated that feed intake and feed conversion efficiency at 7 days of age were not significantly $(\mathrm{P}>0.05)$ affected by in-ovo injection of natural oils, while both were improved during the 21 , and 35 days of age . As a result, at 21 days of age, FCR was significantly $(\mathrm{P}<0.05)$ better in $\mathrm{T} 6$, followed by $\mathrm{T} 5$, T3, and T4 compared to control group. While, FI was the lowest in $\mathrm{T} 6$, $\mathrm{T} 5$ followed by $\mathrm{T} 3$ and $\mathrm{T} 4$ compared to control group. When assesses over the 35 days experimental period, FCR was improved with the best results recorded with $\mathrm{T} 3$, followed by $\mathrm{T} 6$, $\mathrm{T} 4$, and $\mathrm{T} 5$ respectively. While, birds from a group subjected to inovo injection of almond oils consumed less feed compared to other treatment groups. Birds from a group subjected to in-ovo administration of black seed oil consumed more feed compared to other groups. The results of black seeds are in line with Khan et al., (2012) finding, who concluded that feed conversion ratio can be improved by the inclusion of lack seeds to the chicken diet. Results of rosemary oil are in line with Gazalah and Ali (2008) finding, who concluded that feed intake can be improved by adding rosemary leaves to the chicken diet.

Treatments from in-ovo injection with rosemary oil, black seeds oil, and almond oil recorded the lowest mortality percentage (2.5\%). While, treatments from inovo injection with distilled water recorded the highest mortality percentage $(7.5 \%)$ compared to other treatment groups.

\subsection{Serum Analysis}

The data illustrated in table (5) represented the impact of in- ovo injection of some natural oils on serum parameters of broiler chicken. The concentration of total protein and globulin in the serum were significantly increased $(p<0.05)$ with in-ovo injection of rosemary oil and black seeds oil compared to control group. An increase in the globulin shows the effective role of rosemary and black seed in improving immunity due to its function in inhibiting non-enzymatic oxidation and developing and protecting cells (Houghton et al., 2007). 
Results of rosemary came in line with that obtained by ( Ghazalah and Ali ,2008 and Ghozlan et a.l, 2017). However, that of black seeds consistent with (Kumar et al., (2017a) finding who concluded that the total protein concentration in the serum of black seeds offered was higher that of control group and it increased literally when higher doses of black seeds applied to the diet. The serum content of cholesterol, triglyceride, and glucose were significantly $(\mathrm{p}<0.05)$ reduced with in-ovo injection of all-natural oils used in this experiment. Results of olive oil are in accordance with those of Mahmoud et al (2013) who showed that olive oil significantly reduced triglyceride and blood cholesterol when added to broiler diets. Results of rosemary are in agreement with Belenli et al (2015) who reported that rosemary has decreased blood cholesterol. In a study, Gazalah and Ali (2008), added rosemary leaves to broiler diets at a level of $0.5 \%$. They determined that rosemary decreased plasma glucose, total lipid and cholesterol content. Polat et al. (2011), found that serum albumin/globulin ratio, and total cholesterol levels of broilers were significantly decreased by dietary rosemary and its oil rosemary oil. The reduced plasma content of total cholesterol could be attributed to the hypocholesterolemic effect of rosemary oil due to its content of a-pinene, camphor, cineole, borneol (Fatma et al, 2017).

While, these results disagree with Bugdayci and Ergun (2011) finding, who reported that total cholesterol and triglyceride levels in blood serum and humoral immune response did not affected by adding rosemary oil and probiotics to broiler rations.

Results of black seeds are in line with those of Khan et al., (2012). Same results were reported by Al-Beitawi et al (2009) when bacitracin was replaced with crushed black cumin in broiler diets which led to the reduction of total cholesterol in blood serum. This might be due to a possibility that black seeds could have an indirect inhibitory effect on the levels of HMG-CoA reductase, which consider a key enzyme in the biosynthesis of cholesterol (Khan et al, 2012). Moreover, black seeds have the ability to prevent dietary cholesterol absorption due to its content of high number of sterols, especially $\beta$ sitosterol.

Impact of in-ovo injection of some natural oils on thyroid hormone activity and immunoglobulin levels in broiler chicken is showing in table (6). The relationship between the experimental groups was significant $(p<0.05)$ on thyroid hormone activity of broiler chicken. As a result, a significantly higher $\mathrm{T} 3$ was recorded in the birds subjected to in-ovo injection of rosemary oil, black seed compared to other experimental groups. While, T4 was higher in birds subjected to in-ovo administration of rosemary oil, black seeds oil and almond oil compared to other experimental groups. It has been established that thyroid hormones play a great role in adjusting oxidative metabolism of broiler (Sturkie, 1986). The metabolically active thyroid hormone is triiodothyronine (T3), which plays an energetic role in the metabolism of energy and metabolic rate. Metabolic rate could be altered by any declared alteration in thyroid function (Abdel-fattah \& Abdelazeem, 2008). These results indicated the outstanding metabolic rate and growth rate due to in-ovo injection of rosemary oil, black seed oil and almond oil.

The obtained data showed a positive effect of natural oils on stimulating bird's immunity through significant increases in the serum levels of IgM and IgG in allnatural oils -treated groups. These results are in conformity with that obtained by Ghozlan et al(2017) who concluded that the supplementing of rosemary to broiler diet had remarkably progressed immunoglobulin (IgG , $\operatorname{IgM}$ and $\operatorname{Ig} A)$. Same results are obtained in the study of Elnaggar et al. (2016) who pointed out that the inclusion of rosemary to the basal 


\begin{tabular}{|c|c|c|}
\hline \multirow[t]{2}{*}{ Ingredients } & \multicolumn{2}{|r|}{ Percentage (\%) } \\
\hline & $\begin{array}{l}\text { Starter } \\
\text { (0-21days) }\end{array}$ & $\begin{array}{l}\text { Grower } \\
\text { (22-35days) }\end{array}$ \\
\hline Corn & 56 & 62.6 \\
\hline Soybean(44\%) & 34 & 28 \\
\hline Dical. P & 4 & 3.15 \\
\hline Sunflower oil & 4 & 4.35 \\
\hline Common salt & 1 & 1 \\
\hline Vit.Mineral.Premix* & 0.50 & 0.50 \\
\hline DL.Methionine & 0.35 & 0.25 \\
\hline L.Lysine & 0.15 & 0.15 \\
\hline Total & 100.00 & 100.00 \\
\hline $\begin{array}{l}\text { Calculated Nutrient } \\
\text { Composition }\end{array}$ & & \\
\hline ME (kcal/kg) & 2,920 & 3,215 \\
\hline Crude protein (\%) & 22.91 & 20.24 \\
\hline Calcium (\%) & 1.10 & 1.17 \\
\hline Methionine (\%) & 0.59 & 0.56 \\
\hline Lysine (\%) & 1.30 & 1.14 \\
\hline Available p. (\%) & 0.67 & 0.70 \\
\hline
\end{tabular}

serum immunoglobulins ( $\operatorname{Ig} \mathrm{Y}, \operatorname{IgM}$, and $\operatorname{Ig} \mathrm{A})$.

Compared the control diet, the addition of rosemary to layer diets may improve their serum IgM concentration (Alagawany \& Abd El-Hack, 2015). Moreover, AlMufarrej (2014) showed that the immune response of broiler chicken was enhanced by dietary supplementation of black seeds.

\section{CONCLUSION}

The results of current study demonstrated that the

\begin{tabular}{ll}
\hline \hline Treatment G. $\quad$ in-ovo injection \\
\hline T1 & Negative Control (No injection) \\
T2 & Positive control( Injection with distilled water $(0.1 \mathrm{ml})$ \\
T3 & Injection with rosemary oil, using dose $(0.1 \mathrm{ml})$ \\
T4 & Injection with black seed, using dose $(0.1 \mathrm{ml})$ \\
T5 & Injection with olive oil, using dose $(0.1 \mathrm{ml})$ \\
T6 & Injection with almond oil, using dose $(0.1 \mathrm{ml})$ \\
\hline \hline
\end{tabular}

hatchability was significantly increased by in-ovo injection of rosemary oil, almond oil and olive oil at level $0.01 \mathrm{ml}$. Body weight gain and feed conversion ratio of broiler chickens were improved by in-ovo injection of rosemary and black seeds oils. In addition, the natural oils used in the current study reduced total blood cholesterol level and blood glucose in broiler. In-ovo injection of rosemary, olive, almond, and black seeds oils can be used as an immune-modulatory agent to increase birds' resistance against many diseases.

\subsection{List of Tables}

Table 1 Experimental design and distribution of in-ovo
injected eggs

Table 2

Composition of the experimental diets

Vitamin-mineral premix supplied per $\mathrm{kg}$. of diet: vitamin A, 2,200,000 I.U.; vitamin D, 374,000 I.U.; vitamin E, 4,400 I.U.; menadione, $292.6 \mathrm{mg}$.; riboflavin, 1,760 mg.; pantothenic acid, 2,720 mg.; niacin 8,800 mg.; vitamin B12, 6.6 mg.; vitamin B6, 506 mg.; folic acid, 264 mg.; thiamine, 308 mg.; choline, 81,840 mg.; biotin, 79.2 mg.; calcium min, $7.5 \%$; calcium max, $8.4 \%$; Sulfur, $4.5 \%$; cobalt, 290.4 ppm.; copper, 4840 ppm.; iodine, 123.2 ppm.; iron, 2.18\%.; manganese, 2.38\%; selenium, 264 ppm.; zinc, $3.96 \%$.

Table 3

Effect of in- ovo injection of natural oils (Rosemary, black seed, olive and almond) on hatchability (\%), and Initial weight of post hatched chicks. Treatment means with different superscripts are significantly different $(\mathrm{P}<.05)$. 
Table 4

Body weight, feed intake, FCR and mortality rate of broilers hatched from in-ovo injected eggs with different natural oils

\begin{tabular}{lllll}
\hline \hline Treatments & $\begin{array}{l}\text { Body } \\
\text { weight }(\mathrm{g})\end{array}$ & $\begin{array}{l}\text { Feed intake } \\
(\mathrm{g})\end{array}$ & & $\begin{array}{l}\text { FCR of } \\
\text { dead } \\
\text { birds }\end{array}$ \\
\hline 7 days old & & & & \\
T1 & $177 \mathrm{~b}$ & 174.2 & 0.98 & 1 \\
T2 & $176 \mathrm{~b}$ & 176.5 & 1.02 & 2 \\
T3 & $180 \mathrm{a}$ & 179.4 & 1.01 & - \\
T4 & $183 \mathrm{a}$ & 175.4 & 0.96 & 1 \\
T5 & $175 \mathrm{~b}$ & 179.8 & 1.02 & - \\
T6 & $176 \mathrm{~b}$ & 178.7 & 1.03 & - \\
SEM & 3.160 & 2.269 & 0.13 & \\
21 days old & & & & \\
T1 & $880 \mathrm{~b}$ & $1187 \mathrm{a}$ & $1.34 \mathrm{a}$ & 1 \\
T2 & $885 \mathrm{~b}$ & $1184 \mathrm{a}$ & $1.33 \mathrm{a}$ & - \\
T3 & $922 \mathrm{a}$ & $1179 \mathrm{~b}$ & $1.27 \mathrm{~b}$ & 1 \\
T4 & $911 \mathrm{a}$ & $1175 \mathrm{~b}$ & $1.29 \mathrm{ab}$ & - \\
T5 & $880 \mathrm{~b}$ & $1096 \mathrm{c}$ & $1.25 \mathrm{~b}$ & 1 \\
T6 & $876 \mathrm{~b}$ & $1074 \mathrm{c}$ & $1.22 \mathrm{c}$ & 1 \\
SEM & 7.564 & 13.647 & 0.024 & \\
35 days old & & & & \\
T1 & $1867.2 \mathrm{~b}$ & $2990.8 \mathrm{~b}$ & $1.60 \mathrm{a}$ & - \\
T2 & $1860.9 \mathrm{~b}$ & $2987.3 \mathrm{~b}$ & $1.61 \mathrm{a}$ & 1 \\
T3 & $2029.2 \mathrm{a}$ & $2932.9 \mathrm{~b}$ & $1.44 \mathrm{c}$ & - \\
T4 & $1987.2 \mathrm{a}$ & $3026.5 \mathrm{a}$ & $1.53 \mathrm{~b}$ & - \\
T5 & $1810.2 \mathrm{~b}$ & $2832.9 \mathrm{~b}$ & $1.55 \mathrm{~b}$ & 1 \\
T6 & $1774.8 \mathrm{c}$ & $2653.2 \mathrm{c}$ & $1.50 \mathrm{~b}$ & - \\
SEM & .84017 & 22.935 & 0.014 & \\
\hline \hline & & & & \\
\hline
\end{tabular}

ab Treatment means with different superscripts are significantly different $(\mathrm{P}<.05)$.

\section{Table 5}

Serum biochemistry of broilers hatched from in ovo injected eggs with different natural oils

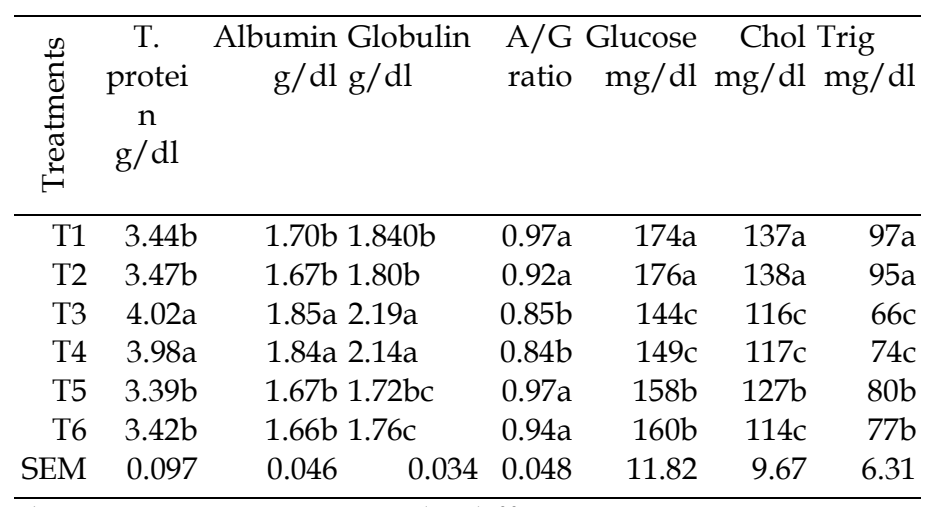

$\mathrm{ab}$ Treatment means with different superscripts are significantly different $(\mathrm{P}<0.05)$.

Table 6

Thyroid gland activity and immunoglobulin levels of broilers hatched from in ovo injected eggs with different natural oils

\begin{tabular}{|c|c|c|c|c|c|c|c|}
\hline \multirow[b]{2}{*}{ Variable } & \multicolumn{7}{|c|}{ Treatments } \\
\hline & $\mathrm{T} 1$ & $\mathrm{~T} 2$ & T3 & $\mathrm{T} 4$ & T5 & T6 & SEM \\
\hline T3 (ng/ml) & $1.64 \mathrm{ab}$ & $1.61 \mathrm{~b}$ & $1.79 a$ & $1.83 a$ & $1.67 \mathrm{~b}$ & $1.64 \mathrm{~b}$ & 0.027 \\
\hline $\mathrm{T} 4(\mathrm{ng} / \mathrm{ml})$ & $6.32 b$ & $6.12 b$ & $8.67 a$ & $8.44 a$ & $6.56 b$ & 7.13ab & 0.15 \\
\hline $\operatorname{IgG}(\mathrm{mg} / \mathrm{ml})$ & $1.71 b$ & $1.74 b$ & $2.41 \mathrm{a}$ & $2.36 a$ & $1.98 \mathrm{a}$ & $2.00 \mathrm{a}$ & 0.010 \\
\hline $\operatorname{IgM}(\mathrm{mg} / \mathrm{ml})$ & $0.91 b$ & $0.77 \mathrm{c}$ & $1.47 \mathrm{a}$ & $1.49 \mathrm{a}$ & $1.11 b$ & $1.34 \mathrm{ab}$ & 0.024 \\
\hline \multicolumn{8}{|c|}{$\begin{array}{l}\text { ab Treatment means with different superscripts are } \\
\text { significantly different }(\mathrm{P}<.05)\end{array}$} \\
\hline Item & \multicolumn{2}{|c|}{ Hatchability \% } & \multicolumn{5}{|c|}{ Body weight of chicks (g) } \\
\hline $\mathrm{T} 1$ & \multicolumn{2}{|l|}{$83.6 \mathrm{~b}$} & \multicolumn{2}{|c|}{44.81} & & & \\
\hline $\mathrm{T} 2$ & \multicolumn{2}{|c|}{$74 c$} & \multicolumn{2}{|c|}{43.96} & & & \\
\hline $\mathrm{T} 3$ & \multicolumn{2}{|c|}{$95 a$} & \multicolumn{2}{|c|}{43.91} & & & \\
\hline $\mathrm{T} 4$ & \multicolumn{2}{|l|}{$84.2 \mathrm{~b}$} & \multicolumn{2}{|c|}{44.50} & & & \\
\hline $\mathrm{T} 5$ & \multicolumn{2}{|l|}{$92.8 \mathrm{a}$} & \multicolumn{2}{|c|}{44.92} & & & \\
\hline T6 & \multicolumn{2}{|l|}{$92.9 \mathrm{a}$} & \multicolumn{2}{|c|}{43.36} & & & \\
\hline SEM & \multicolumn{2}{|l|}{2.38} & \multicolumn{2}{|c|}{0.29} & & & \\
\hline
\end{tabular}

\section{REFERENCES:}

1. Abdel-Fattah, S.A., El-Sanhoury, M.H., El-Mednay, N.M., Abdel-Azeem, F., 2008a. Thyroid Activity, Some Blood Constituents, Organs Morphology and Performance of Broiler Chicks Fed Supplemental Organic Acids. International J. of Poultry Science 7, 215-222.

2. Abdel-Fattah, S.A., El-Sanhoury, M.H., El-Mednay, N.M., Abdel-Azeem, F., 2008b. Thyroid Activity, Some Blood Constituents, Organs Morphology and Performance of Broiler Chicks Fed Supplemental Organic Acids. International J. of Poultry Science 7, 215-222.

3. Abdel-Fattah, S.A., M.H. El-Sanhoury, N.M. El-Mednay, and F. Abdel-Azeem. 2008. "Thyroid Activity, Some Blood Constituents, Organs Morphology and Performance of Broiler Chicks Fed Supplemental Organic Acids." International Journal of Poultry Science 7(3): 215-22.

4. Agarwal, R., M. D. Kharya and R. Shrivastava. 1979a. Antimicrobial and anthelmintic activities of the essential oil of Nigella sativa. Ind. J. Experi. Biol. 17:1264-1265

5. Ajuyah, A. O.; Hardin, R. T.; Sim, J. S., 1993. Effect of dietary full-fat flax seed with and without antioxidant on the fatty acid composition of major lipid classes of chicken meats. Poult. Sci., 72 (1): 125-136

6. Al-Baadani, H., Abudabos, A., Al-Mufarrej, S., Alzawqari, M., 2016. Effects of dietary inclusion of probiotics, prebiotics and synbiotics on intestinal histological changes in challenged broiler chickens. SA J. An. Sci. 46, 157. 
7. Al-Beitawi, N., El-Ghousein, S.S., 2008. Effect of feeding different levels of Nigella sativa seeds (Black cumin) on performance, blood constituents and carcass characteristics of broiler chicks. Int. J. Poult. Sci. 7:715-721

8. Al-Kassie, G. A. M., Al-Jumaa, Y. M. F., \& Jameel, Y. J. (2008). Effectof probiotic (Aspergillus niger) and prebiotic(Taraxacumofficinale)on blood picture and biochemical properties ofbroiler chicks. Department of Veterinary Public Health,Veterinary Medical College, University of Baghdad, Baghdad,IraqInternational Journal of Poultry Science, 7, 1182e1184

9. AL-MUFARREJ, S.I. (2014) Immune-responsiveness and performance of broiler chickens fed black cumin (Nigella sativa L.) powder. Journal of Saudi Society of Agricultural and Science 13: 75-80.

10. Bagchi M, Milnes M, Williams C, Balmoori J, et al. (1999b). Acute and chronic stress-induced oxidative gastrointestinal injury in rats, and the protective ability of a novel grape seed proanthocyanidin extract. Nutr. Res. 19: 1189-1199

11. Belenli D, Udum D, Şule Cengiz S and Polat U. (2015). Influence of various volatile oils as a Dietary supplement on biochemical and performance parameters in broilers. Journal of Biology Environment Science, 9, 47-55.

12. Betul, A.Y., Muhammed, A.T., Mehmet, G., Fatih, Y., Ahmet, Y., 2017. The effect of Rosemary (Rosmarinus officinalis L.) extract supplemented into broiler diets, on performance and blood parameters. GSC Biol. Pharm. Sci. 2, 001-009.

13. Bhanja S K and Mandal A B. 2005. Effect of in ovo injection of critical amino acids on pre and post hatch growth, immunocompetence and development of digestive organs in broiler chickens. Asian-Australasian Journal of Animal Science 18: 524-31

14. Bhanja S K, Mandal A B and Johri T S. 2004a. Standardization of injection site, needle length, embryonic age and concentration of amino acids for in ovo injection in broiler breeder eggs. Indian Journal of Poultry Science 39 (2): 105-11.

15. Borghei-Rad, S.M., Zeinoaldini, S., Zhandi, M., Moravej, H., Ansari, M., 2017. Feeding rosemary leaves powder ameliorates rooster age-related subfertility. Theriogenology 101, 35-43.

16. Botsoglou, N.A, Yannakopoulos, A.L, Fletouris, D.J, Tserveni-Goussi, Fortomaris, P.D. Effect of dietary thyme on the oxidative stability of egg yolk J. Agric. Food Chem., 45 (1997), pp. 3711-3716

17. Bugdayci, k. emre, Ergün, A., 2011. The effects of supplemental essential oil and/or probiotic on performance, immun system and some blood parameters in broilers. Ankara Universitesi Veteriner Fakultesi Dergisi 58, 279-284.

18. Çabuk, M., Bozkurt, M., Alçiçek, A., Akbap, Y., Küçükyýlmaz, K., 2006. Effect of a herbal essential oil mixture on growth and internal organ weight of broilers from young and old breeder flocks. South African Journal of Animal Science 36, 135-141.

19. Celiktas,O.Y.,Kocabas,E.E.H.,Bedir,E.F.,Sukan,V.,Ozek,T., Baser,K.H.C.,2007.Antimicrobialactivitiesofmethanolextr actsandessentialoilsofRosmari-

nusofficinalis, dependingonlocationandseasonalvariations .FoodChem.100,553-559.

20. CHERIAN, G., WOLFE, F.H., SIM, J.S., 2006. Feeding Dietary Oils with Tocopherols: Effects on Internal Qualities of Eggs During Storage. Journal of Food Science 61, 15-18.

21. ÇiFtçï, M., ŞiMşek, Ü.G., Azman, M.A., Çerçï, İ.H., Tonbak, F., 2013. The Effects of Dietary Rosemary (Rosmarinus officinalis L.) Oil Supplementation on Performance, Carcass Traits and Some Blood Parameters of Japanese Quail Under Heat Stressed Condition. Kafkas Univ Vet Fak Derg.

22. Deighton, N., Glidwell, S.M., Goodman, B.A., Morrison, I.M., 1993. Electron para-magnetic resonance of gammairradiated cellulose and lignocellulosic material. J.Food Sci. Technol. 28, 45-55

23. Farag RS, Badei AZM, Hewadi FM, EL-Baroty GS (1989a ). Antioxidant activity of some spice essential oils on linoleic acid oxidation in aqueous media. Am. Oil. Chem. Soc., 66: 792-799

24. Galobart, J., A. C. Barroeta, M. D. Baucells, and F. Guardiola, 1999. Oxidation in fresh and spray-dried $\omega 3$ and $\omega 6$ fatty acid enriched eggs: Vitamin E vs. Canthaxanthin. Pages 165- 169 in: Proceedings of the VIII European Symposium on the Quality of Eggs and Egg Products. Bologna, Italy.

25. Galobart, J., A. C. Barroeta, M. D. Baucells, and F. Guardiola, 2001. Lipid oxidation in fresh and spray-dried eggs enriched with $\omega 3$ and $\omega 6$ polyunsaturated fatty acids during storage as affected by vitamin $\mathrm{E}$ and canthaxanthin supplementation. Poultry Sci. 80:327-337.

26. Gilani, A. H., Q. Jabeen and M. A. U. Khan.2004. A Review of Medicinal Uses and Pharmacological Activities of Nigella sativa. Pakistan J. Biol. Sci. 7:441-451.

27. Jamroz, D., J. Orda, C. Kamel, A. Wiliczkiewicz, T. Wertelecki,and J. Skorupinska. 2003. The influence of phytogenic extractson performance, nutrient digestibility, carcass characteristics, andgut microbial status in broiler chickens. J. Anim. Feed Sci. 12:583-596

28. Karpinska, M., J. Borowski and M. Danowska-Oziewicz, 2000. Antioxidative activity of rosemary extract ion lipid fraction of minced meat balls during storage in a freezer. Nahrung, 44: 38-41.

29. Khan, S.H., Ansari, J., Haq, A. u., Abbas, G., 2012. Black cumin seeds as phytogenic product in broiler diets and its effects on performance, blood constituents, immunity and caecal microbial population. Italian Journal of Animal Science 11, e77. 
30. Kolahdooz, M.; Nasri, S.; Modarres, S. Z.; Kianbakht, S. and Huseini, H. F., 2014. Effects of Nigella sativa seed oil on abnormal semen quality in infertile men: A randomized, double-blind, placebo-controlled clinical trial. Phytomedicine,21,901-905.

31. Krause, E.L., Ternes, W., 1999. Bioavailability of the antioxidative thyme compounds thymol and p-cymene2,3-diol in eggs. Eur Food Res Technol 209, 140-144.

32. KUMAR, P., PATRA, A.K., MANDAL, G.P., SAMANTA, I. and PRADHAN, S. (2017a) Effect of black cumin seeds on growth performance, nutrient utilization, immunity, gut health and nitrogen excretion in broiler chickens. Journal of the Science of Food and Agriculture 97: 37423751

33. Manafi M, Hedayati M and Yari M. (2014). Effectiveness of rosemary (Rosmarinus officialis L.) essence on performance and immune parameters of broilers during Aflatoxicosis. Advances in Life Sciences, 4, 166-173

34. Mathlouthi, N., Bouzaienne, T., Oueslati, I., Recoquillay, F., Hamdi, M., Urdaci, M., Bergaoui, R., 2012. Use of rosemary, oregano, and a commercial blend of essential oils in broiler chickens: In vitro antimicrobial activities and effects on growth performance1. Journal of Animal Science 90, 813-823.

35. Moreno, S., Scheyer, T., Romano, C.S., Vojnov, A.A., 2006. Antioxidant and antimicrobial activities of rosemary extracts linked to their polyphenol composition. Free Radic. Res. 40, 223-231.

36. Nielsen, D.C., Anderson, R.L., Bowman, R., Aiken, R., Vigil, M., Benjamin, J.G., 1999. Winter Wheat and Proso Millet Yield Reduction Due to Sunflower in Rotation. Journal of Production Agriculture 12, 193-197.

37. Polat, U., Yesilbag, D., Eren, M., 2011. Serum Biochemical Profile of Broiler Chickens Fed Diets Containing Rosemary and Rosemary Volatile Oil. J.Biol.Environ.Sci.13,23-30.

38. Radwan Nadia, L., Hassan, R.A. , Qota, E. M. \& Fayek, H.M., 2008. Effect of natural antioxidant on oxidative stability of eggs and productive and reproductive performance of laying hens. Int. J. Poult. Sci. 7, 134-150.

39. Schwarz, S., Kehrenberg, C., Walsh, T.R., 2001. Use of antimicrobial agents in veterinary medicine and food animal production. Int. J. Antimicrob. Agents 17, 431-437. 7

40. Singletary, K.W., and Rokusek, J.T. (1997). Tissue-specific enhancement ofxenobiotic detoxification enzymes in mice by dietary rosemary extract.PlantFoods Hum Nutr.50: 4753

41. Superchi, P., Talarico, L., Beretti, V., Bonomi, A., 2005a. Effect of dietary administration of oil extract from rosemary on reproductive efficiency in boars. Italian Journal of Animal Science 4, 479-481.

42. Superchi, P., Talarico, L., Beretti, V., Bonomi, A., 2005b. Effect of dietary administration of oil extract from rosemary on reproductive efficiency in boars. Italian Journal of Animal Science 4, 479-481.

43. Tekeli, A., L. Celik, H.R. Kutlu and M. Gorgulu, 2006. Effect of dietary supplemental plant extracts on performance, carcass characteristics, digestive system development, intestinal microflora and some blood parameters of broiler chicks. Proceedings of 12th European Poultry Conference, September 10-14, 2006, Verona, Italy, pp: 307-308.

44. Toghyani, Mehdi, Toghyani, Majid, Gheisari, A., Ghalamkari, G., Eghbalsaied, S., 2011. Evaluation of cinnamon and garlic as antibiotic growth promoter substitutions on performance, immune responses, serum biochemical and haematological parameters in broiler chicks. Livestock Science 138, 167-173.

45. Windisch WM, Schedle K, Plitzner C, Kroismayr A. Use of phytogenic products as feed additives for swine and poultry. Journal of Animal Science 2008;86(14 Suppl.):E140-E148. 